\author{
JACEK KORDEL \\ https://orcid.org/0000-0003-2334-292X \\ University of Warsaw, Faculty of History
}

\title{
THE MOTIF OF THE 'BLOODBATH OF TORUŃ’ IN VOLTAIREAN WRITINGS CONCERNING THE DISSIDENT QUESTION OF 1767/68 AND THE FIRST PARTITION OF POLAND
}

\begin{abstract}
The 'Tumult of Torun' of 1724, which resulted in the sentencing to death of the mayor and a dozen or so townsmen (the so-called 'bloodbath' or 'bloody court'), brought about a veritable deluge of publications. It has become widely accepted in literature that these writings fundamentally impacted the development in Western public opinion of the notion that eighteenth-century Poland was an intolerant country. In 1767-71, Voltaire placed his pen at the service of the Russian empress, and his propaganda texts provided support for the diplomatic and military offensive of the court of Saint Petersburg in Poland. One of the more significant themes that appeared in the papers commissioned by the Russians and also in the philosopher's correspondence was that of the 'Tumult of Torun' of July 1724 and the death sentences that were passed against the city's mayor and a dozen or so townspeople.

Keyw ords: Catherine II, the dissident question of 1766-68, confessional relations in eighteenth-century Poland, the ‘Bloodbath of Thorn' of 1724, Thorner Blutgericht, Voltaire.
\end{abstract}

A minor incident which occurred in July 1724 and was initially participated in solely by students of the Jesuit College in Torun (Thorn) and the municipal academic gymnasium resulted in events that were to receive nationwide - and even European-wide - attention. ${ }^{1}$ The judgement of

${ }^{1}$ The events of 1724 are thoroughly represented in the literature. The following are the most important recent works: Samuel Feinauer, " Tragoedia Thoruniensis»: Ein europäisches Medienereignis des frühen 18. Jahrhunderts und sein Widerhall in Diplomatie und Publizistik', unpublished doctoral dissertation, Universität Stuttgart, 2017. For the background and course of events, see Stanisław Salmonowicz, 'O toruńskim tumulcie z roku 1724', OiRP, 28, 1983, pp. 161-84; Jerzy Dygdała, ‘W cieniu głębokich konfliktów wyznaniowych (1719-1732)', in Historia Torunia, ed. Marian Biskup, 
the assessor's court, which sentenced to death the city's mayor and twelve persons considered as being directly involved in the riots, guilty of disturbing public order, or failing to react to the disturbance appropriately, aroused strong emotions among Protestants. The public execution, which came to be known in historiography as the 'bloodbath' or the 'bloody court' (Thorner Blutbad, Thorner Blutgericht), gave rise to a flood of publications. ${ }^{2}$ In later years, the view that these writings were of decisive importance for the development among European public opinion of an image of Poles as religious fanatics became established in the historical sciences. ${ }^{3}$ Was this indeed the case? The views of a broad part of Western historiography, summarized by Martin Schulze Wessel, are not borne out by the sources.

In the first years of the reign of Stanislaus II Augustus, which coincided with the most significant increase in propaganda efforts aimed at shielding the political and military intervention of Catherine II on behalf of Polish Protestants and Orthodox Christians, then known as 'dissidents', the events of Torun were not seen as a significant landmark in

3 vols, Toruń, 1992-2006, vol. 2, part 3: Między barokiem i oświeceniem 1660-1793, ed. Jerzy Dygdała, Stanisław Salmonowicz and Jerzy Wojtowicz, 1996, pp. 175-205.

${ }^{2}$ Karol Estreicher, who revealed nearly 130 publications devoted to the topic, observed: 'The events that occurred in Torun engendered such a torrent of journalistic output throughout Europe - particularly in the German, Dutch and English languages - that we have with all certainty omitted more than one brochure which is inaccessible or unknown... And assuredly, a good few remain hidden in manuscripts', quoted from Joanna Milewska-Kozłowska, 'Druki dotyczące Tumultu Toruńskiego w zbiorach starych druków Biblioteki Uniwersytetu Mikołaja Kopernika w Toruniu', Rocznik Toruński, 34, 2007, pp. 207-46 (pp. 207-08). Henryk Baranowski (Bibliografia miasta Torunia, 2 vols, Toruń, 1996-99, vol. 1: Do roku 1971, 1999, pp. 60-72) mentioned more than 150 titles. A number of items were added to this set by Daniel Bellingradt, Flugpublizistik und Öffentlichkeit um 1700: Dynamiken, Akteure und Strukturen im urbanen Raum des Alten Reiches, Stuttgart, 2011, pp. 307-33, 462-80.

3 'Während [...] im 17. Jahrhundert hugenottische Schriftsteller Polen als Vorbild für Toleranz darstellten, entstand in der Folge der Thorner Ereignisse das Konzept des intoleranten, von Europa abgewandten Polen als fester, abrufbereiter Topos. Dies war nicht bloß die Konstruktion einiger hervorragender westeuropäischer Intellektueller, sondern ist vielmehr als Ergebnis der weitverbreiteten Flugschriftenpropaganda in der Thorner Affäre anzusehen. Der Aufstand von Thorn und die Urteile gegen den Magistrat der Stadt bildeten mit ihrer weit reichenden medialen Wirkung die Zäsur für die politische Geographie Polens: Einflussreiche Flugschriften entwarfen Polen als einen eigentlich ungeschichtlichen Raum, in dem Wildheit und Intoleranz herrschten [...]. Es trug zugleich dazu bei, Polen als einen separaten politisch-geographischen Raum zu konstruieren, in dem nicht Aufklärung sondern Intoleranz herrschte', Martin Schulze Wessel, Religiöse Intoleranz, grenzüberschreitende Kommunikation und die politische Geographie Ostmitteleuropas im 18. Jahrhundert, in Europäische Öffentlichkeit: Transnationale Kommunikation seit dem 18. Jahrhundert, ed. Jörg Requate, Martin Schulze Wessel, Frankfurt, 2002, pp. 63-78 (p. 76). 
the history of confessional minorities in the republic of the szlachta. The Russian defamation campaign soon engaged the leading writers of the Enlightened literary commonwealth, with Voltaire foremost among them. In his letters and pamphlets, which he penned using materials supplied by the Russians, and the correspondence he maintained with monarchs, thinkers and writers, Voltaire made at least a few references to the events of 1724. The following comments aim to present threads concerning the 'Tumult of Torun' in propaganda publications elaborated by the philosopher from Ferney at the turn of the 1770s and in his correspondence. My objective is to provide an answer to the question as to how Voltaire used the motif of the 'Bloodbath of Torun' in his works, why he recalled memories of the events of 1724, to what degree was he independent in this regard, and to what extent was he guided by instructions received from Saint Petersburg. However, before I proceed to an analysis of the utilization of the 'Bloodbath of Torun' in Voltaire's writings from the turn of the 1770s, I will attempt to answer one other question - namely, to what extent were these works known to the European public opinion, and thus to what degree could they have contributed to the perception of the Polish Commonwealth as an intolerant state.

It seems that until the turn of the 1770s, the 'religious tumult' of Torun was written about mainly in Protestant countries. Jean-Alphonse Turrettini, the well-known Genevan theologist, was right when in the first weeks of 1725 he declared that 'the events of Torun gave rise to a great commotion in Germany'. ${ }^{4}$ In the lexicon of Johann Heinrich Zedler, the prominent publisher from Leipzig, the entry concerning the 'Tumult of Torun' was written in a typically confessional spirit: 'The Jesuits had been insulting the Lutherans for some length of time, and they seized upon the opportunity and quenched their impudence, passionately aroused, with the blood of the innocent'. ${ }^{5}$ In the Neue Erdbeschreibung, a canonical work authored by the German geographer Friedrich Büsching, professor of philosophy at the University of Göttingen (1754-61) and after that pastor of the Lutheran parish in Saint Petersburg and senior councillor of the consistory in Berlin, the

${ }^{4}$ Jean Alphonse Turrettini to Jean Le Clerc, Geneva, 13 February 1725, in Jean Le Clerc, Epistolario, published by Maria Grazia Zaccone-Sina and Mario Sina, 4 vols, Firenze, 1987-97, vol. 4: 1719-1732 e indici generali, 1997, p. 289.

5 'Es hatten nehmlich die Jesuiten den Evangelisch-Lutherischen schon lange Zeit allen Tort angethan, bis sie endlich die Gelegenheit erhaschten, ihren erhitzten Muth in unschuldigen Blute völlig abzukühlen', 'Thoren', in Grosses vollständiges Universal-Lexicon aller Wissenschaften und Künste, 68 vols, Leipzig and Halle, 1732-54, vol. 43, 1745, col. 1673. 
'Bloodbath of Torun' was depicted as one of many inflammatory events in the history of relations between Catholics and Evangelicals: 'a crowd gathered for some completely trivial reason; the next day, its anger rose beyond measure, and, using violence, it forced its way into the Jesuit school and college, for which the mayor, Rösner, and a few other persons had to pay with their heads, while the city was punished with a fine'. ${ }^{6}$ It would appear that contemporary observers of religious relations in the Polish Commonwealth and other countries of Europe did not accept the 'Tumult of Torun' as a significant landmark. At the turn of the eighteenth century, Europe once again became the scene of an immense struggle that was denominational at its core. The accession of the Catholic Prince Johann Wilhelm to the Electorate, the conversion of the Elector of Saxony, Frederick Augustus I, and his elevation to the Polish Crown, the Emperor's attempts at limiting the rights of Protestants - which the Treaty of Westphalia had secured - and the further deterioration of the legal position of the Huguenots (in 1724, the court of Versailles issued a fresh edict targeting the religious rights of the Protestant minority) all influenced the Evangelicals' collective perception to a considerably greater extent than the events of Torun. ${ }^{7}$

In francophone literature, the 'Bloodbath of Torun' aroused decidedly less interest. In their Encyclopédie, which presented the totality of knowledge about the world, Denis Diderot and Jean Le Rond d'Alembert did not mention the 'Tumult of Torun' at all. The sixteenth volume of the publication, which was printed in 1765 , informs us that in the city of Torun, where Lutherans form a majority, the Cathoics, thanks to the protection of the Polish state, may freely conduct their services. The author of the article devoted to Torun added that 'Nicolaus Copernicus, so widely known in the field of astronomy, was born in this very city in 1473. It was he who discovered the true system of the world and the celestial bodies'. ${ }^{8}$ Perusing this brief entry, readers would also learn

6 'entstund aus einer geringer Ursache [...] ein Auflauf, welcher des folgenden Tages noch heftiger wurde, so dass der Pöbel mit Gewalt in die Schule und das Jesuiten-Collegium drang und allerhand Gewaltthätigkeiten ausübete, wofür der Präsident Rösner, nebst einigen andern, den Kopf hergeben, und die Stadt eine Geldbusse erlegen muste', Anton Friderich Büsching, Neue Erdbeschreibung. Erster Theil, welcher Dänemark, Norwegen, Schweden, das ganze rußische Kaisertum, Preussen, Polen, Hungarn und die europäische Türkey, mit denen dazu gehörigen und einverleibten Ländern, enthält, Hamburg, 1754 , p. 863.

${ }^{7}$ Cf. Christian Mühling's monumental study, Die europäische Debatte über den Religionskrieg (1679-1714): Konfessionelle Memoria und internationale Politik im Zeitalter Ludwigs XIV., Göttingen, 2018.

8 'Quoique le luthéranisme y domine, les Catholiques ont la liberté d'y célébrer les 
that in 1703, during the Great Northern War, the city was captured by Charles XII, who proceeded to destroy its fortifications. ${ }^{9}$ Further, in the thirteenth tome, which was published in the same year, the paragraph concerning Prussia informs us that Catholics, Lutherans and Calvinists inhabited royal Prussia. ${ }^{10}$ The Encyclopédie does not provide detailed information about relations between representatives of the various denominations, specifically about any conflicts or disputes.

We should further note that Voltaire did not mention the events of Torun in any of his historical works ${ }^{11}$. It would seem that he associated Torun primarily with Copernicus. In the spring of 1738 , Voltaire, while chastening Frederick, the successor to the Prussian throne, for the linguistic blunders which he had committed in a sample of writing submitted to the philosopher, stated thus: 'and this has been written by a Copernican prince, a prince in whose state Copernicus was born; I am certain that he was born in Torun, and I consider that your Royal House may hold certain claims to Torun'. ${ }^{12}$ While analysing the collection of Voltairean correspondence published by Theodore Besterman, I found another mention concerning Torun only under the year 1767, by which time Voltaire had placed his pen at the service of the Russian empress and was writing in support of the 'dissident affair' that she pursued. ${ }^{13}$

cérémonies de leur religion, en vertu de la protection de la Pologne', 'Thorn', in Encyclopédie ou dictionnaire raisonné des sciences, des arts et des métiers, 35 vols, Paris, $1751-72$, vol. 16, 1765, p. 198 (it is worth noting that no changes were made to the entry in successive editions of the Encyclopédie, cf. 3rd edn, vol.16, Livourne, 1775, p. 282).

${ }^{9}$ Ibid.

10 'On y professe également la religion catholique, la luthérienne et la réformée', 'Prusse', in Encyclopédie ou dictionnaire raisonné des sciences, vol. 13, 1765, p. 532.

${ }^{11}$ If the thinker had indeed considered the events of Torun to be an important landmark, we could have expected him to have noted the fact at least in the Annales de l'Empire (particularly in the chapter 'De l'Allemagne du temps de Joseph Ier et de Charles VI', in Voltaire, Euvres complètes, 52 vols, ed. Louis Moland, Paris, 1877-85, vol. 13, 1878, pp. 608-16, or in Histoire de l'empire de Russie sous Pierre le Grand, parts 1-2, in Voltaire, Cuvres complètes, vol.16,1878, pp.371-639).

12 'C'est un prince copernicien qui parle, un prince dans les états de qui Copernic est né, car je le crois né à Thorn, et je pense que votre maison royale pourrait bien avoir des droits sur Thorn', Voltaire to Frederick II, 25 April 1738, D1484. All of Voltaire's letters are quoted from Theodore Besterman's edition (Voltaire, Correspondence and Related Documents, ed. Theodore Besterman, 51 vols, Oxford, 1968-77, Les œuvres complètes de Voltaire, vols 85-135), and only their numbers are given below.

${ }^{13}$ For more information on Voltaire's relations with the court of Saint Petersburg, cf. George Peabody Gooch, 'Catherine the Great and Voltaire', The Contemporary Review, 181-82, 1952, pp. 214-20, 288-93; idem, 'Voltaire as Historian', in idem, Catherine the Great and Other Studies, London, 1954, pp. 199-274; Carolyn Wilberger, Voltaire's Russia: Window on the East, Oxford, 1976; Inna Gorbatov, Catherine the Great and 
We should further add at this point that until the mid-1760s, French public opinion tended to express on the whole favourable opinions regarding confessional relations in the Polish Commonwealth. ${ }^{14}$ The Encyclopédie, quoted above, informs us that the republic of the szlachta was a tolerant state, wherein the representatives of the various Christian denominations and other religions lived in harmony. In the article concerning Poland, which was published in the twelfth volume, printed in 1765, we read thus: 'indeed, we find in Poland Calvinists, Lutherans, Greek schismatics, Muslims, and Jews' ${ }^{15}$ Describing the beginnings of the Protestant movement in the Polish Commonwealth, the author notes that when this grouping first appeared, during the reign of Sigismund I the Old, 'its progress was proportionate to the violence applied against it'. ${ }^{16}$ The Encyclopaedist did not mention the details of persecution, remarking only in general that Sigismund I the Old had introduced the death penalty for 'affiliation with the movement' ${ }^{17}$ Following the death of the last of the Jagiellonians, 'the Polish Commonwealth decided that from then on, every king acceding to the throne would pledge toleration for all religions'. ${ }^{18}$ This was due to 'the spirit of peace and moderation of the monarchs, which had passed down onto the nation.' The author surmised that Poland was spared of the religious wars that ravaged Europe in the sixteenth and seventeenth centuries thanks to such benevolence. The Encyclopaedist observed that the state of the szlachta did not witness events such as the Parisian St Bartholomew's Day Massacre of 1572 or the English Gunpowder Plot of 1605; it did not see a 'senate stained with blood, murdered kings, brothers fighting against brothers'. When recapitulating his deliberations on the traditions of toleration in the Polish Commonwealth, he stated that Poland was the example of a country in which 'a great many fewer people had been burned at the stake' than in other European

the French Philosophers of the Enlightenment: Montesquieu, Voltaire, Rousseau, Diderot and Grimm, Bethesda, MD, 2006, pp. 59-114.

${ }^{14}$ Ryszard Wołoszyński, Polska w opiniach Francuzów XVIII wieku, Warsaw, 1964, pp. 76-80.

15 'On voit effectivement en Pologne des calvinistes, des luthériens, des grecs schismatiques, des mahométans et des juifs', 'Pologne', in Encyclopédie ou dictionnaire raisonné des sciences, vol. 12, 1765, p. 930.

16 'La religion protestante étoit entrée dans le royaume sous Sigismond I. et ses progrès augmentoient à proportion des violences qu'on exerçoit contre elle', ibid., p. 917.

17 'Lorsque la Pologne a commencé à discourir, un de ses rois, Sigismond I. prononça la peine de mort contre la religion protestante', ibid, p. 930.

18 'La république statua que désormais, les rois en montant sur le trône, jureroient la tolérance de toutes les religions', ibid. 
states. ${ }^{19}$ Furthermore, in the entry of the Encyclopédie devoted to dissidents, we read that they enjoyed complete freedom of worship. The fact of being a Protestant did not preclude anyone from occupying positions in the state administration. However, the article's author failed to add that the convocation Sejm, which assembled following the death of Augustus II the Strong, finally deprived non-Catholics of this opportunity. Moreover, although the Encyclopaedist mentioned that dissidents were sometimes forced to demand that their religious rights be fully respected, he did not elaborate on the matter. ${ }^{20}$ In the Encyclopédie, neither Poland nor Poles were presented unfavourably in the broad context of religious and confessional relations. ${ }^{21}$

Views on the topic of religious freedom in the Polish Commonwealth were expressed by Voltaire, who, similarly to the majority of Western European intellectuals, knew relatively little about the country, ${ }^{22}$ broadly

19 'Cet esprit de paix et de douceur dans les rois, passa à la nation. Elle prit fort peu de part à toutes les guerres de religion qui désolerent l'Europe au XVI et XVII siècle. Elle n'a eu dans son sein ni conspiration des poudres, ni saint Barthelemy, ni sénat égorgé, ni rois assassinés, ni des frères armés contre des frères et c'est le pays où l'on a brûlé moins de monde pour s'être trompé dans le dogme', ibid.

20 'Dissidens, l'on nomme ainsi en Pologne ceux qui sont profession des religions Luthérienne, Calviniste et Grecque. Ils doivent jouir en Pologne du libre exercice de leur religion, qui, suivant les constitutions, ne les exclut point des emplois. Le roi de Pologne promet par les pacta conventa de les tolérer et de maintenir la paix et l'union entr'eux; mais les dissidens ont eu quelquefois à se plaindre de l'inexécution de ces promesses', Encyclopédie ou dictionnaire raisonné des sciences, vol. 4, 1754, p. 1048.

${ }^{21}$ Contrary to the opinion of Maciej Forycki (Anarchia polska w myśli oświecenia: Francuski obraz Rzeczypospolitej szlacheckiej u progu czasów stanisławowskich, Poznań, 2004, p. 124), the Encyclopaedists were not of the opinion that the issue of fanatical flagellants concerned Poland alone ('L'Italie, l'Allemagne et la Pologne sont inondées de ces maniaques destructeurs de leur être', 'Fanatisme', Encyclopédie ou dictionnaire raisonné des sciences, vol. 6, 1756, p. 397).

${ }^{22}$ We should observe that shortly after his death, Augustus II the Strong became the subject of an apologia entitled Leben und Thaten Friedrich Augusti II. des Großen, Königs der Pohlen, und Churfürstens zu Sachsen beschrieben von Herrn von Voltaire. This work had nothing to do with the French philosopher, and indeed the Saxons were well aware of the fact. In November 1733, the 'Silesian Leander', Gottlieb Stolle, wrote thus to Johann Christoph Gottsched: 'Man schleppt sich hier mit einer Zeitung, als wenn der Herr Voltaire selbst das Leben dieses grossen Monarchen heraus geben wolle. Ich glaube aber nicht, daß was daran sey', Jena, 2 November 1733, Johann Christoph Gottsched, Briefwechsel: Unter Einschluß des Briefwechsels von Luise Adelgunde Victorie Gottsched: Historisch-kritische Ausgabe, Berlin and New York, 2007-, vol. 2: 1731-1733, published by Detlef Döring, Rüdiger Otto and Michael Schlott, 2008, p. 536. In reality, it was a reprint of a book by Johann Gottfried Mittag, a musician and cantor from Leipzig, which had been published in 1733 by the printing house of August Martini in Leipzig. 
reflected the sentiments of the Encyclopaedists. ${ }^{23}$ In his Histoire de Charles XII, printed in 1731, the philosopher observed that the Swedish king had acted as the protector of Polish Lutherans. However, he did not specify the details of what the monarch had actually done or give any examples of the wrongs and persecution from which he had shielded his co-religionists. ${ }^{24}$ Whereas in his Essai sur les mœurs, which was published in 1756, Voltaire described Poland as a tolerant country that was peaceably inclined towards its neighbours, ${ }^{25}$ where Protestants, due to their large number, had gained freedom of conscience towards the end of the sixteenth century. ${ }^{26} \mathrm{~A}$ singular example of the szlachta's respect for different religious views was, as he maintained, the fate of the Polish Brethren. The philosopher believed that the Arians, who had behaved disloyally towards the Polish state during the Swedish Deluge, had to suffer just punishment once the Swedish invasion had been repulsed. He surmised that the Polish Brethren, who were deprived of political rights in the wake of the conflict, remained in Poland. He further presumed that, although they did not influence the course of state affairs, they still enjoyed the freedom of religion. Irrespective of the fact that Voltaire was mistaken - and this shows that his knowledge of Polish history was comparatively limited (although, as we know from elsewhere, he was keenly interested in the affairs of the non-Trinitarian movement) - it is essential to observe that he believed that the repressive measures employed against the Polish Brethren were thoroughly justified, had been undertaken in defence of the sovereignty and integrity of the state, and were not founded in issues of confessiona-

${ }^{23}$ Cf. Emanuel Rostworowski, 'Wolter a Polska', KH, 75, 1968, 4, pp. 849-64 (pp. 849-53); Stanisław Fiszer, L'image de la Pologne dans l'œuvre de Voltaire, Oxford, 2001.

24 'Enfin toutes les difficultés étant aplanies [...] avoir protégé sa religion luthérienne au milieu des catholiques, détrôné un roi, couronné un autre', Voltaire, Histoire de Charles XII, in idem, Euvres complètes, vol. 16, p. 228.

25 'Quant à la religion, elle causa peu de troubles dans cette partie du monde', Voltaire, Essai sur les mœurs et l'esprit des nations, vol. 3, in idem, Euvres complètes, vol. 13, p. 129; 'C'est encore le seul royaume qui n'ait point eu l'esprit de conquête, occupé seulement de défendre ses frontières', ibid., p. 126. Voltaire did not give much attention to Poland in this work. References to Polish affairs concern mainly the country's archaic social relations, the serfdom of the peasants, and the szlachta's absolute power over their subjects: 'La Pologne est une république aristocratique où le peuple est esclave' (Voltaire, Essai sur les mœurs et l'esprit des nations, vol. 2, in idem, Euvres complètes, vol. 12,1878, p. 129); 'Les cultivateurs sont esclaves, et où les nobles sont rois' (ibid., p. 111); 'Ces possesseurs des terres sont les maîtres de tout, et que les cultivateurs sont esclaves' (ibid., p. 226).

26 'Les factions catholique et protestante, qui avaient troublé tant d'États, pénétrèrent enfin chez cette nation. Les protestants furent assez considérables pour se faire accorder la liberté de conscience en 1587', Voltaire, Essai sur les mœurs et l'esprit des nations, vol. 3, p. 126. 
lism. ${ }^{27}$ Even in the Traité sur la tolérance, brought out in 1763, the Polish Commonwealth served as a positive reference point. The philosopher further argued that the Catholic clergy - ultimately pragmatic in its approach - was itself interested in maintaining the peaceful coexistence of the numerous denominations which resided in the country: 'In Poland, a certain Bishop of Warmia had a leaseholder who was an Anabaptist and a tax-collector who was a Socinian. It was suggested that he expel and persecute the one for not believing in consubstantiality and the other for having baptised his son only at the age of fifteen. He responded that they will be condemned in the other world but that he very much needs them in the present'. ${ }^{28}$

In the mid-1760s, and thus still before the court of Saint Petersburg engaged him, the philosopher regularly commented on the most critical denominational issues of the day, followed by practically all of Enlightened Europe. He took the initiative to research their causes and strongly criticized any judicial rulings he viewed as unjust. Following the sentencing to death of Jean Calas, a Protestant merchant from Toulouse accused of murdering his son, who had purportedly been planning to convert to Catholicism, interest in the issue of religious freedom reached its zenith. The philosopher also stood up in defence of the Sirven family from Mazamet (a small township in Occitanie), sentenced to death in absentia after being accused of ill-treating their daughter. The latter had intended to enter a Catholic convent. Further, he protested against the execution of Jean-François de la Barre, a young nobleman from Abbeville in Picardy charged with profaning the cross and reading indecent literature. ${ }^{29}$

Nevertheless, already in the years 1767-71, when European public opinion grew interested in the dissident question in Poland, Voltaire wrote several brochures in support of the Russian intervention in the Polish Commonwealth. ${ }^{30}$ The first of these, if we discount the Lettre sur

${ }^{27}$ Forycki, Anarchia polska, pp. 126-27.

28 'Un évêque de Varmie, en Pologne, avait un anabaptiste pour fermier, et un socinien pour receveur; on lui proposa de chasser et de poursuivre l'un, parce qu'il ne croyait pas la consubstantialité, et l'autre, parce qu'il ne baptisait son fils qu'à quinze ans: il répondit qu'ils seraient éternellement damnés dans l'autre monde, mais que, dans ce monde-ci, ils lui étaient très-nécessaires', Voltaire, Traité sur la tolérance, in idem, CEuvres complètes, vol. 25, 1879, p. 34.

${ }^{29}$ Peter Gay, Voltaire's Politics: The Poet as Realist, New Haven, CT, 1988; Marc Chassaigne, Le procès du chevalier de La Barre, Paris, 1920; Janine Garrisson, L'Affaire Calas, miroir des passions françaises, Paris, 2004; Dominique Inchauspé, L'intellectuel fourvoyé: Voltaire et l'affaire Sirven, 1762-1778, Paris, 2004.

${ }^{30}$ Catherine II and Frederick II expected that Stanisław II August, who had been elevated to the throne of the Piasts and the Jagiellonians in the autumn of 1764, would 
les panégyriques published in April or at the latest in May 1767, was the Essai historique et critique sur les dissensions des Églises de Pologne. ${ }^{31}$ When elaborating the text, Voltaire made use of materials supplied by the Russians. Towards the end of August 1767, availing himself of the agency

enact a law broadening the rights of the Protestant and Orthodox szlachta. Initially, Saint Petersburg did not make precise the scope of its demands. When, however, the coronation Sejm of 1764 did not accept any concessions in favour of dissenters, Catherine, outraged by such 'insubordination', demanded that the Sejm of 1766 offer far-reaching religious toleration and equality of political rights to dissidents. Neither the Russians nor the Germans wanted any marked improvement of the dissidents' lot. In a letter sent to Voltaire in February 1767, the Prussian king admitted: 'Je voudrais que les dissidents fussent heureux, mais sans enthousiasme' (Frederick II to Voltaire, Potsdam, 20 February 1767, D13981). The court of Saint Petersburg was worried that granting political rights to dissenters would increase the number of Russian peasants fleeing to Poland. At the same time, Frederick II was aware that far-reaching changes in the legal status of Protestants could bring about the migration of Prussian subjects to the Polish Commonwealth. Referencing historic political traditions, the Russian empress and the Prussian king intended to use the Orthodox and Protestant minorities as a vehicle for broadening and strengthening their influences in Poland. Another critical factor that was always given serious consideration at the court of Saint Petersburg was Catherine II's striving to authenticate herself in the eyes of the Orthodox hierarchy in Russia. Having been born to an impoverished German princely family and baptised in the Evangelical rite, the empress, even though she later converted to Orthodox Christianity, had to seek favour with the Orthodox Church - all the more so as at the beginning of her reign she had upheld Peter III's decision to secularize the landed estates of the Church. Finally, it was essential to heed European public opinion, which was keenly interested in confessional issues and the problem of religious toleration. In the autumn of 1764 , the empress wrote explicitly to Nikita Ivanovich Panin, Russia's unofficial minister of foreign affairs, that the realization of her demands regarding the 'dissident question' would bring her fame in Russia and throughout Europe. Zofia Zielińska, Polska w okowach 'systemu pótnocnego' 1763-1766, Cracow, 2010, pp. 203-04. Regarding the dissident issue in the policies of Catherine II and Frederick II, cf. Jerzy T. Lukowski, The 'Szlachta' and the Confederacy of Radom, 1764-1767/68: A Study of the Polish Nobility, Rome, 1977; Maria Cecylia Łubieńska, Sprawa dysydencka 1764-1766, Warsaw, 1911; Boris V. Nosov, Ustanovlenie rossiiskogo gospodstva v Rechi Pospolitoi, 1756-1768 gg., Moscow, 2004; Zielińska, Polska w okowach. Cf. also Michael G. Müller, 'Anmerkungen zur Diskussion über religiöse Toleranz und Dissidentenfrage in Polen in der zweiten Hälfte des 18. Jahrhunderts', Kwartalnik Neofilologiczny, 55, 1998, pp. 417-26; idem, 'Toleration in Eastern Europe: The Dissident Question in Eighteenth-Century Poland-Lithuania', in Toleration in Enlightenment Europe, ed. Ole P. Grell and Roy Porter, Cambridge, 1999, pp. 212-29. Concerning the circumstances of Voltaire's co-operation with the court of Saint Petersburg and the behind-the-scenes discussions which took place between Russian diplomats and Voltaire: Jacek Kordel, 'Catherine the Great, Voltaire, and the Russian Intervention in Poland, 1767-1771', in Recht zur Intervention Pflicht zur Intervention?: Zum Verhältnis von Schutzverantwortung, Reputation und Sicherheit in der Frühen Neuzeit, ed. Christoph Kampmann, Julian Katz and Christian Wenzel, Baden-Baden, 2021, pp. 499-543.

${ }^{31}$ I have discussed aspects of the brochure which do not touch upon confessional question in the following work: 'Królestwo anarchii': W poszukiwaniu nowożytnych 
of Aleksandr Romanovich Vorontsov, the Russian envoy to The Hague, Nikolai Vasil'evich Repnin, Catherine II's ambassador in Warsaw, provided Voltaire with "numerous prints and manuscripts concerning this great matter [that is, the issue of equal rights of dissidents - J.K.], upon which the empress has embarked for the glory of Russia and the good of Poland'. ${ }^{32}$

Daniel Ernest Jabłoński's Jura et libertates dissidentium in religione christiana, both editions of which had been printed before the 'Tumult of Torun' took place, ${ }^{33}$ was one of the works sent to Ferney. ${ }^{34}$ The brochure Fundamenta liberae religionis evangelicorum, reformatorum et graecorum... ${ }^{35}$ published in 1764, explained the legal basis for the dissidents' claims for equality of political rights and freedom of religion, to a lesser degree accentuating instances of religious persecution. The inference was applied to remind readers of those clauses of the Treaty of Oliwa and the Treaty

wyobrażeń o Rzeczypospolitej i jej mieszkańcach, Warsaw, 2020, pp. 188-98. Cf. Jerzy T. Lukowski, 'Unhelpful and unnecessary: Voltaire's Essai historique et critique sur les dissensions des Églises de Pologne (1767)', in Voltaire et ses combats: Actes du Congres International 'Voltaire et ses combats...' tenu du 29 septembre au 5 octobre 1994 a Oxford et a Paris, ed. Ulla Kölving and Christiane Mervaud, Oxford, 1997, pp. 645-54.

32 'Il y a quelques semaines que mr le comte de Voronzoff, ambassadeur à la Haye, me fit l'honneur de m'envoyer les lettres de mr le prince de Repnin. Je reçus [...] un gros paquet [...] contenant plusieurs mémoires imprimés et manuscrits concernant toutes les grandes choses que fait l'impératrice pour la gloire de la Russie et pour le bonheur de la Pologne.' Voltaire to Dmitrii Alekseevich Golitsyn, Ferney, 7 October 1767, D14470 (Besterman mistakenly assumed that the philosopher had addressed this letter to Dmitrii Alekseevich Golitsyn). Voltaire (contrary to the suppositions of Wanda Dźwigała, 'Voltaire's Sources on the Polish Dissident Question', Studies on Voltaire and the Eighteenth Century, 241, 1986, pp. 187-202 (p. 190) was aware from the very beginning that all of the materials came from Repnin; cf. Voltaire to Élie Bertrand, Ferney, 7 May 1770, D16333. Cf. also Daniel Beauvois and Emanuel Rostworowski, introduction to Essai historique et critique sur les dissensions des Églises de Pologne, in Les œuvres complètes de Voltaire, vol. 63A: CEuvres de 1767, ed. William H. Barber and Ulla Kölving, Oxford, 1990, pp. 241-60; Zofia Zielińska, 'Głos rosyjskiego arystokraty o Polsce z 1766 r.', Miscellanea Historico-Archivistica, 11, 2000, pp. 335-44.

33 [Daniel Ernest Jabłoński], Jura et libertates dissidentium in religione christiana, in regno Poloniae, et M.D. Lithuaniae..., Stargard, 1715.

${ }^{34}$ A list of the materials sent by Nikolai V. Repnin to Voltaire through the agency of Aleksandr R. Vorontsov, Warsaw, 7/18 July 1767, Arkhiv vneshnei politiki Rossiiskoi imperii, Moscow (hereafter AVPRI), fonds 80, series 1, no. 1095, fol. 8. Wanda Dźwigała, 'Voltaire and Poland: the Historical Works', Studies on Voltaire and the Eighteenth Century, 267, 1989, pp. 103-118, and Stanisław Fiszer, L'image de la Pologne, attempted to recreate a list of the materials upon which the philosopher had based his argumentation using the Voltaire library catalogue.

${ }^{35}$ Fundamenta liberae religionis evangelicorum, reformatorum et graecorum in Regno Poloniae et Magno Ducatu Lithvaniae... / Deduction fondamentale des libertés de religion dont les lutheriens, les reformes et les grecs doivent jouir dans Le Royaume de Pologne et Le Royaume de Lithuanie..., [n.p.], 1764. 
of Perpetual Peace (the Grzymultowski Peace), which granted Poland's neighbours the right to intervene in denominational relations in the Commonwealth. We should note as an aside that at the turn of 1767 when work was already underway on creating associations of dissident szlachta under Catherine II's protection, the Russian ministry was anxious to ensure that this element would be underscored in the manifestos of future confederacies. It demonstrated that the protection of dissenters was the legal obligation of Russia and other powers. ${ }^{36}$ Referencing the Confederacy of Vilnius of 1599 , which had brought together Evangelicals and Orthodox Christians in a common bloc, the Fundamenta liberae religionis went on to explain the reasons why the courts of Saint Petersburg and Berlin had decided on a joint intervention in defence of the Protestant and Orthodox denominations. Repnin was particularly concerned with finding convincing arguments that would clarify why the issues of the Protestant and Orthodox citizens of the Polish Commonwealth should be considered together. Thus, Voltaire also received a manuscript memorandum authored by Repnin, most probably in the spring of 1767, which, taking as its point of departure the Confederacy of Vilnius of 1599, stressed the commonality of interests of Protestants and Orthodox Christians, and thereby Russia's right to act on behalf of all non-Catholics. ${ }^{37}$ This issue was to constitute the crux of the memorandum which Voltaire had been commissioned to write. ${ }^{38}$ Repnin fur-

${ }^{36}$ Referring to the international obligations formerly undertaken by Poland, Nikita I. Panin reminded Nikolai V. Repnin just how important it was to emphasize the rights of the rulers of neighbouring states concerning this issue, Saint Petersburg, 31 January/11 February 1767, Diplomaticheskaia perepiska Imperatritsy Ekateriny II, part 4: 1766-1767, published by Fiodor A. Biuler, Saint Petersburg, 1889, p. 309, SIRIO, vol. 67. Provisions envisaging protection for Polish Protestants had already been introduced by the Treaty of Oliwa (1660) and successive Prussian-Swedish treaties $(1696,1703$, 1707). Clauses concerning the Evangelical minority were included in the Hanoverian Alliance of 1725, which brought together Prussia, France and Great Britain. The Russians based their title to speak in defence of Orthodox Christians on the Treaty of Perpetual Peace of 1686. A separate article of the Russo-Prussian Treaty of 1730 , which was reiterated in subsequent agreements, had particular importance. It conjoined Protestants and Orthodoxes in a common bloc under the support of Berlin and Saint Petersburg. Preussens Staatsverträge aus der Regierungszeit König Friedrichs I., published by Victor Loewe, Leipzig, 1923, pp. 291, 306 n. 3; cf. Józef Feldman, Sprawa dysydencka za Augusta II, Cracow, 1924; Gotthold Rhode, Brandenburg-Preußen und die Protestanten in Polen 1640-1740, Leipzig, 1941, passim. Significant observations may also be found in Andrew C. Thompson's study, entitled Britain, Hanover and the Protestant Interest 1688-1756, Woodbridge, 2006, pp. 97-132.

37 [Nikolai V.Repnin], Mémoire sur les affaires des dissidents en Pologne, Rossiiskaia natsional'naia biblioteka, Saint Petersburg, Biblioteka Vol'tera, 9-335, no. 7828.

38 'Je remarque encore à Votre Excellence, qu'elle peut voir et faire remarquer à 
ther wanted Voltaire to demonstrate in his text that many Protestants and Orthodoxes had been active on the Polish political scene towards the end of the sixteenth century. This would reinforce the arguments presented by the court of Saint Petersburg, which declared that its sole objective was to restore previous legal relations. ${ }^{39}$

The next brochure sent to the philosopher, which had been printed in Saint Petersburg towards the end of 1766, Exposition des droits des dissidents, joints et ceux des puissances intéresses à les maintenir, ${ }^{40}$ also focused on the legal bases upon which dissidents could found their demands. However, the only example which it provided of the tribulations experienced by both Protestants and Orthodoxes was that of the Sword-Bearer of Wieluń, Andrzej Piotrowski (who was not, however, named in the pamphlet), who had not been allowed to take part in the deliberations of the Sejm in 1718; further, a general mention was made of other 'abuses, instances of violence and illegal acts'. ${ }^{41}$ We should add that Repnin purportedly handed out this brochure to dissidents so that they could gain a better understanding of their rights. ${ }^{42}$

Further, no register of historical oppression and injustices was included in the Russian empress's declaration that Repnin presented on 26 March $1767,{ }^{43}$ or in Panin's printed letter to Repnin which accompanied it (dated 3/14 February 1767). ${ }^{44}$ At once heralding a Russian intervention in defence of the dissidents, both these documents were also sent to Voltaire. However, a catalogue of repressions (along with a legal

Monsieur de Wolter d'après l'union des grecs et dissidents, faite en 1599', Nikolai V. Repnin to Aleksandr R. Vorontsov, Warsaw, 7/18 July 1767, AVPRI, fonds 80, series 1, no. 1095 , fol. 6.

39 'Combien il y'a voit encore de grecs et dissidents dans le sénat polonais, parce que tous ceux comme vous savez, qui sont palatins au castellans sont sénateurs', ibid.; 'Dans ce tems [the reign of Sigismund II Augustus - J.K.] la reforme évangélique etoit dans ses plus grands progrès et il y avoit plus de dissidents dans le sénat polonois et dans toutes les placées du gouvernement que de catholique', Mémoire sur les affaires des dissidents en Pologne.

${ }^{40}$ Exposition des droits des dissidents, joints à ceux des puissances intéressées a les maintenir, Saint Petersburg, 1766.

${ }^{41}$ Ibid., p. 22.

${ }^{42}$ Nikita I. Panin to Nikolai V. Repnin, Saint Petersburg, 20/31 January 1767, Diplomaticheskaia perepiska Imperatritsy Ekateriny II, part 4, p. 288.

${ }^{43}$ Déclaration de la part de Sa Majesté, l'impératrice de toutes les Russies à Sa Majesté le roi et à la République de Pologne, [Saint Petersburg], [1767]; cf. Catherine II to Nikolai V. Repnin, 31 January/11 February 1767, Diplomaticheskaia perepiska Imperatritsy Ekateriny II, part 4, p. 305.

${ }^{44}$ Lettre de monsieur Panin au prince Repnin, [n.p.], [1767]; cf. Nikita I. Panin to Nikolai V. Repnin, Saint Petersburg, 31 January/11 February, Diplomaticheskaia perepiska Imperatritsy Ekateriny II, part 4, p. 302. 
inference) was attached to the Acts of the Confederacies of Torun ${ }^{45}$ and Słuck, ${ }^{46}$ the contents of which had undoubtedly been consulted with Repnin, similarly to the analogous manifestoes of the confederates of Radom. ${ }^{47}$ The difficult plights of many Evangelical families (among others the Goltzes, Mojaczewskis, Dziembowskis, Mielęckis, Potworowskis and Bojanowskis) brought up by the author of the proclamation were the consequence not of a limitation of freedom of religion, but, and this was stated outright, of the exclusion of Evangelicals from holding public office. ${ }^{48}$ The problem, therefore, did not concern religious toleration but equality of political rights. The Act of the Confederacy of Torun recalled the cases of Piotrowski and Zygmunt Unrug. ${ }^{49}$ Mention was made, albeit sparingly, of the execution of the mayor and townsmen of Torun: 'indeed, we could find more unjust decrees, but if these we pass over in silence, we cannot do the same as regards the bloody execution, during which dissident blood was profusely spilled'. ${ }^{50}$ The manifesto of the

${ }^{45}$ Confédération faite par les dissidents du royaume de Pologne à Thorn le 20 mars l'année 1767, [n.p.], [1767], the same in Polish Konfederacya jchmciow panow dissydentow $z$ Wielkiey y Małey Polski y z Pruss w Toruniu uchwalona dnia 20 marca Roku Panskiego 1767, [n.p.], [1767].

${ }^{46}$ Acte de la confédération des nobles et citoyens du Grand Duché de Lituanie du rit grec et de deux confessions évangeliques, fait à Sluck l'an 1766 le 20 de Mars, [n.p.], [1767], the same in Polish Konfederacya rycerstwa y obywatelow W. X. Litt. tak religii staroruskiey jako tez oboyga wyznania ewangelickiego, zaczęta w Słucku, roku 1767 dnia 20 miesiaca..., [n.p.], [1767].

${ }_{47}$ Cf. Nikita I. Panin to Nikolai V. Repnin, Saint Petersburg, 31 January/ 11 February 1767, Diplomaticheskaia perepiska Imperatritsy Ekateriny II, part 4, p. 309.

${ }^{48}$ Confédération faite par les dissidents du royaume de Pologne à Thorn.

${ }^{49}$ In 1715, Zygmunt Unrug was sentenced to death by the Crown Tribunal in Piotrków Trybunalski. Both the course of the trial and the verdict were examples of judicial injustice. Andrzej Potocki, Clerk of the Magistrates' Court of Gniezno, had found notes and entries in Unrug's silva rerum that he considered insulting to the Roman Catholic faith and proceeded to bring an accusation against him to the Crown Tribunal. Recognizing Unrug's theological disquisitions as blasphemous, the court sentenced him to death (however, he managed to escape to Saxony) and ordered the seizure of his entire property, awarding one half to Potocki as the delator. While in exile, Unrug gained the support of the Sorbonne. According to French lawyers, he had not committed the crime of blasphemy. Availing himself of this favourable opinion, he turned to the Pope with a plea for intervention. In the autumn of 1723, Innocent XII convened the Council of Cardinals, which issued a resolution annulling the sentence of the Crown Tribunal. However, the nuncio, fearing that the szlachta would accuse the Holy See of meddling in Polish internal affairs, did not make use of the document. The death sentence was repealed only by the Sejm of 1726, while Unrug did not live to see the restitution of his assets, dying in 1732. Aleksander Kraushar, Sprawa Zygmunta Unruga: Epizod historyczny z czasów saskich 1715-1740, 2 vols, Cracow, 1890.

${ }^{50}$ Konfederacya jchmciow panow dissydentow $z$ Wielkiey y Małey Polski y $z$ Pruss $w$ Toruniu, the same in French 'Qu'on veut passer sous silence sans pouvoir néanmoins oublier la tragédie de Thorn, ou l'on nageoit dans le sang des dissidens exécutes inhumainement', Confédération faite par les dissidents du royaume de Pologne à Thorn. 
Lithuanian szlachta also gave examples of the wrongs supposedly suffered by Protestants and Orthodoxes at the hands of the Catholic majority. ${ }^{51}$

In order to better comprehend the situation prevailing in Poland, Voltaire supplemented the texts he received from Vorontsov with the account of one of the Encyclopaedists, Jean-François Marmontel. Even before the formation of the dissident confederacies, in mid-February 1767, Voltaire asked Marmontel to use the agency of Marie-Thérèse Geoffrin, the hostess of a Parisian literary salon. The latter happened to be in Warsaw in the summer of 1766 to obtain information about Poland's state of affairs and pass it on to him. ${ }^{52}$ These critical particulars reached Ferney only at the beginning of August. Marmontel reported to Voltaire that he had obtained his intelligence from a 'well-informed source', namely the Russian diplomat Kaspar von Saldern, who visited Warsaw in 1766. He did not, however, provide the philosopher with the identity of his informer. According to the Encyclopaedist's account, the legal situation of the dissidents was deteriorating practically daily. When they finally turned for help to the Russian empress, 'this honourable queen asked the Polish king not for mercy but for justice for the dissidents and the repeal of all that which recent Sejms had resolved to their disadvantage. ${ }^{53}$ The king allegedly submitted her request along with the dissidents' demands to parliament. Marmontel went on to claim that from that moment on, the king started turning attention to the fact that the dissidents too were his subjects, that he considered their complaints justified, and that he felt obliged to represent them at sessions of the Sejm the very institution which had previously done them so much harm. Then, 'there was a great commotion in the Sejm [...]. The empress was informed of the fierceness of the debate. She ordered the dissidents to act following the law and form a confederacy. A certain friend of humanity told the empress that if the dissidents established a confederacy without any protection [...], a civil war would erupt in Poland. It would therefore be best to aid them in advance of avenging them after the event. Heeding this advice, the empress sent 20,000 soldiers, as I think, to Poland to protect the dissidents in case of need. ${ }^{54}$ The reasons for the Russian

${ }^{51}$ Konfederacya rycerstwa y obywatelow W. X. Litt.

${ }^{52}$ Voltaire to Jean-François Marmontel, Ferney, 12 February 1767, D13950.

53 'Cette auguste souveraine fit demander au roi de Pologne, non pas faveur mais justice pour les dissidents, et que tout ce qu'on avoit décidé à leur préjudice dans les précédentes diètes fût révoqué.' Jean-François Marmontel to Voltaire, Aachen, 7 August 1767, D14343.

54 'Il s'éleva dans la diète un si grand tumulte [...]. Elle fut instruite de cette délibération violente, et alors elle fit dire aux dissidents de se confédérer, comme les lois 
intervention in Poland given by Saldern constituted the fundamental axis of the argumentation used to legitimize the activities undertaken by the court of Saint Petersburg. For generations, the dissenters had experienced hostility from the increasingly more intolerant Catholic majority. Those who were unable to find justice in their own homeland were forced to appeal for foreign assistance. The matter concerned not just political or religious rights of which dissendents had been deprived over decades, but the threat to their very physical existence if they should ever try to regain their entitlements. The Russian empress was interceding on behalf of the Orthodox and Protestant inhabitants of the Commonwealth, demanding the restitution of the prerogatives they had enjoyed in previous centuries. In his presentation, the Russian diplomat conveniently omitted the division into political and religious rights. It should be mentioned here that the issue of the 'Bloody Court' of Torun did not appear in the Saldern-Marmontel account.

In his Essai historique et critique sur les dissensions des Églises de Pologne, which was commissioned by the Russians and written using the materials sent to him from Warsaw, Voltaire made the general assumption that the issue of religious toleration had particular importance for the life of the state and society: 'the matter concerns the entitlements of citizens, their natural freedoms, the observance of solemnly accepted rights, the fulfilment of pledges - the fundamental interests of humankind. [...] High positions may be overthrown, and sects may die out, but human rights are eternal. ${ }^{55}$ According to Voltaire, a breakthrough in the approach of state authority and the Catholic majority to the Protestant and Orthodox minorities in the Polish Commonwealth occurred during Augustus II's reign. Recalling the political events of the Great Northern War, the philosopher wrote that this monarch 'had been dethroned by the hostile Lutheran king and then returned to power by the Orthodox tsar. ${ }^{56}$ The Catholic Church had started to repress the Protestants, for whom Charles XII was the pro-

les y autorisaient. Mais un ami de l'humanité représenta à l'impératrice que si les dissidents se confédéroient sans avoir pour les protéger [...], il s'élèveroit en Pologne une guerre civile [...], et qu'il valoit mieux les secourir d'avance, que d'avoir à les venger. Ce conseil obligea la czarine d'envoyer (je crois) vingt mille hommes en Pologne pour protéger les dissidents en cas de besoin.' Ibid.

55 'Il s'agit de leurs droits, de la liberté naturelle, de l'exécution des lois solennelles, de la foi des serments, de l'intérêt du genre humain. [...] Les dignités peuvent s'abolir, les sectes peuvent s'éteindre; le droit des gens est éternel.' Joseph Bourdillon [Voltaire], Essai historique et critique sur les dissensions des Églises de Pologne, in idem, Euvres complètes, vol. 26, 1879, p. 456.

56 'Il fut détrôné par les armes d'un roi luthérien, et rétabli par les victoires d'un czar de la communion grecque.' Ibid., p. 460. 
tector. The persecution reached its zenith in 1717 when the rights of religious minorities were limited to a hitherto unheard-of extent. Augustus II himself strove to behave loyally towards his non-Catholic subjects and attempted to block unjust legislation. Nevertheless, despite the king's efforts to maintain religious peace, 'the stronger faction gained the upper hand over the weaker, and violence began to take its toll. ${ }^{57}$ Voltaire readily admitted that in comparison with the situation existing in other European countries, the plight of the Polish dissenters was by no means hopeless: 'It is true that no stakes were lit - the stakes that had once, in the times of the Cathars (Albigensians), reduced an entire province to ashes [...]. Wheels and gallows had not yet appeared in public squares [...]. No mention was being made in Poland of copying the massacre that had occurred on St Bartholomew's Day [...]. Finally, however, the innocent started to be deprived of their freedoms and lives. Furthermore, once the first blows fell, no one knew when they would stop. [...] Soon, churches, schools and hospitals were being vandalized. ${ }^{58}$ For Voltaire, the central point of reference was the events of Torun, which had nearly symbolic importance: 'Poland seemed predestined to share the fate of so many countries that had been devastated by religious conflict. ${ }^{59}$ Proceeding to a description of the events of July, the philosopher wrote thus: 'the bloody execution in Torun renewed the old calamities that had undermined Christianity in numerous other states. A few unfortunate students of the Jesuit College and a few Protestant townspeople got involved in a quarrel' ${ }^{60} \mathrm{He}$ attributed the entirety of the blame for starting the unrest to the Catholic youths: 'it is certain beyond doubt that the students of the Jesuits, being the aggressors, were most to blame. ${ }^{61}$ Not only did the Jesuits provoke their Evangelical neighbours, but they also demanded

57 'Le parti le plus fort l'emporta sur le plus faible; la violence se donna carrière.' Ibid., p. 461.

58 'Il est vrai qu'on ne ralluma pas les bûchers qui mirent autrefois en cendres toute une province du temps des Albigeois [...]. Les roues et les gibets ne furent point d'abord dressés dans les places publiques [...]. On n'a point encore parlé en Pologne d'imiter les massacres de la Saint-Barthélémy [...]. Mais enfin on a commencé à ravir à des innocents la liberté et la vie. Quand les premiers coups sont une fois portés, on ne sait plus où l'on s'arrêtera. [...] Bientôt on démolit des églises, des écoles, des hôpitaux de dissidents.' Ibid., pp. 461-62.

59 'La Pologne semblait donc destinée à subir le sort de tant d'autres États que les querelles de religion ont dévastés.' Ibid., p. 463.

60 'Enfin, en 1724, l'exécution sanglante de Thorn renouvela les anciennes calamités qui avaient souillé le christianisme dans tant d'autres États. Quelques malheureux écoliers des jésuites et quelques bourgeois protestants ayant pris querelle', ibid., p. 462.

${ }_{61}$ 'Il est certain que les écoliers des jésuites, ayant été les agresseurs, étaient les plus coupables.' Ibid. 
that they receive punishment incommensurate with their offence. Voltaire was quick to stress that there was no bloodshed when the Evangelical townspeople stormed into the Jesuit College. Indeed, the townspeople's only misdeed had been to 'take a few pictures of saints and, unfortunately, the image of the Mother of God, which was then thrown into the mud. ${ }^{62}$ The thinker explained that 'it was a great transgression to take from the Jesuits the images and above all the image of the Holy Virgin. [...] The likeness of the Virgin Mary is most worthy of reverence, but so is human blood. ${ }^{63}$ The philosopher explained that desecration of the picture of the Mother of God is viewed as a terrible crime by Catholics, however not so by Protestants, who did not recognize the cult of images. Thus, he took the position that 'the court should have ordered the Protestants to return it or provide another image as an act of apology, repair the damage done, and handed out only moderate punishment'. ${ }^{64}$ Whereas the Jesuits, 'capable of exacting revenge in the name of God and His Mother, had their way, despite the intervention of all the neighbouring powers. ${ }^{65}$ Consequently, the matter was referred to the assessor's court and this passed sentence following the wishes of the Jesuits. When depicting the course of the execution, Voltaire wrote of the beheading of president Rösner, whose sole wrongdoing had been 'not to oppose the tumult sufficiently' ${ }^{66}$ According to the philosopher's account, the other persons who had been sentenced to death were either burned alive or hanged; this was a departure from the truth, for no one had been burned alive. Voltaire was convinced that the riot participants had been sentenced for profaning the image of the Mother of God, that is, for religious reasons, and not for disturbing public order, which was punished with exceptional severity throughout Europe. He pointed to important parallels. Just as Copernicus had given the world a new system of the universe by formulating the theory of heliocentrism, so now had finally come the time for man to discover a new system of tolerance. He expounded on this interpretation in a clearly flattering letter to Andrei Petrovich Shuvalov, a close collaborator of Catherine II, which he sent shortly after finishing work on the Essai historique et critique sur les

62 'On emporta quelques images de leurs saints, et malheureusement une image de la Vierge, qui fut jetée dans la boue.' Ibid.

${ }^{63}$ 'C'était une grande faute d'avoir pris les images des jésuites, et surtout celle de la sainte Vierge. [...] L'image de la vierge Marie est très-respectable; mais le sang des hommes l'est aussi.' Ibid.

${ }^{64}$ 'Les protestants devaient être condamnés à la rendre ou à en fournir une autre, à demander pardon, à réparer le dommage à leurs frais, et aux peines modérées', ibid.

65 'Les jésuites demandèrent vengeance au nom de Dieu et de sa mère; ils l'obtinrent malgré l'intervention de toutes les puissances voisines.' Ibid.

66 'Le président Rosner, accusé de ne s'être pas assez opposé au tumulte’, ibid., p. 463. 
dissensions des Églises de Pologne. Addressing the Russian empress, he wrote: 'It is a beautiful thing when a woman teaches us how to be wise. The truth about our world came from Torun [the theory of heliocentrism - J.K.], from the very city where blood was spilled because of the Jesuits. The true system of morality and politics will come to us from Saint Petersburg'. ${ }^{67}$ According to the philosopher, the Russian empress laid the foundations for a new world based on tolerance by bringing about a revolution in political and social relations. The events of 1724 rapidly gained further symbolic importance, for it was in Torun, 'over which there still hung the pall of blood spilled at the instigation of the Jesuits', ${ }^{68}$ that a confederacy of dissident szlachta was formed in 1767.

In order to demonstrate just how serious the difficulties experienced by dissenters were, Voltaire proceeded to give specific examples. However, he recalled the case of Unrug without clarifying that the sentence passed by the Crown Tribunal had not been carried out, ${ }^{69}$ and alluded to Piotrowski's non-admission to the parliamentary session in $1718 .^{70}$ Interestingly, while presenting the example of Andrzej Moczulski, the Consenior of Vileyka and Preacher of Biržai, who in 1754 was assaulted on a public road by a Catholic priest from Biržai, eventually dying of his injuries, the philosopher failed to indicate that justice was duly dispensed, with the ecclesiastic being suspended. $\mathrm{He}$ also recalled the case of Michał Jaugiel, whom an Augustinian monk had attacked. He mentioned a parish priest from Kaunas who profaned the deceased upon encountering a Lutheran funeral procession. In addition, he mentioned the Jesuits who purportedly used force to convert the Orthodox residents of Mstsislaw and wrote of the frequent removal of the municipal rights of craftsmen in Lithuanian cities who failed to participate in Catholic services. ${ }^{71}$

67 'Il est temps qu'on devienne sage; mais il est beau que ce soit une femme qui nous apprenne à l'être. Le vrai système de la machine du monde nous est venu de Thorn, de cette ville où l'on a répandu le sang pour la cause des jésuites. Le vrai système de la morale et de la politique des princes nous viendra de Petersbourg', Voltaire to Andrei P. Shuvalov, Ferney, 30 September 1767, D14450.

68 'Dans cette même ville de Thorn qui fumait encore du sang que les jésuites avaient fait répandre.' Joseph Bourdillon [Voltaire], Essai historique et critique sur les dissensions des Églises de Pologne, p. 464.

${ }^{69}$ Ibid., p. 462.

70 Ibid.

${ }^{71}$ We should note that both manifestoes - that of Torun and of Slutsk - enumerated further instances which were not presented by Voltaire in his brochure, among others the case of captain Kehler (or Kleyner), who was beheaded for taking part in theological disputes (it was said that he had protested against taunts levelled at Martin Luther), the kidnapping and imprisonment of Andrzej Hruszynowski, the 
Voltaire was considered an authority, and his catalogue of injustices purportedly experienced by Protestants and Orthodoxes, duly presented in the Essai historique et critique sur les dissensions des Églises de Pologne, was reprinted without any modification in the Encyclopédie ou dictionnaire universel raisonné des connaissances humaines of Fortunato Bartolomeo de Felice, ${ }^{72}$ published in 1772.

As the tone of the writings and manifestoes commissioned by or written at the behest of the court of Saint Petersburg clearly shows, the Russians were not overly concerned with keeping the injustices endured by Protestants and Orthodox Christians alive in the shared memory. Rather, emphasis was placed on their loss of political rights, and the entitlement of the powers to intervene in their defence. An excellent example in this regard is the Act of the Confederacy of Torun, in which the 'bloodbath' was mentioned only in one sentence. It would seem that a deliberate effort was made not to highlight instances of persecution; maybe it was assumed that the scale of these happenings was not excessive. ${ }^{73}$ What is more, we cannot exclude the possibility that policymakers in Saint Petersburg recognized the legitimacy of the verdict of the assessor's court, which ascertained that the Protestants had fomented social unrest. From the Russian point of view, three aspects were of crucial importance: recalling the former rights and entitlements of the Protestant and Orthodox szlachta (in order to create the impression that the objective of the Russian involvement was only to reinstate the pre-existing state of affairs), establishing the right of the Russian empress to commence an intervention in defence of the Protestants based on international law, and, finally, expounding the reasons why the court of Saint Petersburg was standing up in the defence of both Protestants and the Orthodox. We may therefore assume that Voltaire's

priest of the Orthodox parish in Hołożewo, or of the tribulations suffered by Bishop Jerzy Konisski in July 1759, when he was prevented from becoming a pastor in one of the parishes. Cf. Konfederacya jchmciow panow dissydentow z Wielkiey y Małey Polski y $z$ Pruss $w$ Toruniu; Konfederacya rycerstwa y obywatelow W. X. Litt.

${ }^{72}$ The fact that he cited the very same examples of the tribulations suffered by dissidents supports the supposition that the author of the Encyclopédie d'Yverdon made use of the Voltairean text, and not of the confederate manifestoes. Dissidens, in Fortunato Bartolomeo de Felice, Encyclopédie ou dictionnaire universel raisonné des connaissances humaines, 58 vols, Yverdon, 1770-80, vol.14, 1772, pp. 189-93, examples of repression, p. 192.

${ }^{73}$ At this point we should recall the words of Sergei G. Dolgorukov from August 1723: 'Takozh i dissidentom naglykh obid ia nikakikh ne vizhu', quoted from: Jacek Burdowicz-Nowicki, 'Polityka Piotra I w związku ze sprawą toruńską 1724 r.', in W cieniu wojen i rozbiorów: Studia z dziejów Rzeczypospolitej XVIII i poczactków XIX wieku, ed. Urszula Kosińska, Dorota Dukwicz and Adam Danilczyk, Warsaw, 2014, p. 80. 
original input consisted of devoting a lengthier passage of text to the events of Torun and citing the person of Copernicus to draw a comparison with the achievements of Catherine II. But the question arises: why did the philosopher from Ferney decide to accentuate the repressions suffered by the Protestants and the Orthodox to such a degree? It is possible, perhaps, that he thought that a religious issue would receive wider publicity than a simple matter of political rights.

The Essai historique et critique sur les dissensions des Églises de Pologne was the first of many writings glorifying the Russian empress that emerged from the 'manufactory of Ferney'. However, by then, the question of equality of rights for Polish dissenters had been settled as planned by the Russian court. The extraordinary Sejm of 1767-68, terrorized by the kidnapping of resistant senators, had adopted the regulations concerning dissidents forced upon it by Nikolai V. Repnin; these acts introduced complete equality of political rights and broadened the catalogue of religious freedoms. In this situation, Voltaire's next objective became to discredit the Confederacy of Bar, which was formed on 29 February 1768 as a response of part of the szlachta to the Russian diktat imposing equality of political rights for dissidents. Thus, another opportunity to recall the events of Torun presented itself towards the end of July 1768, following publication of the brochure Discours aux confédérés catholiques de Kaminiek en Pologne. Par le major Kaiserling au service du roi de Prusse, which was reprinted thrice in the same year. It was intended to call into question the political objectives and, indeed, the motivations of the Bar movement. The titular narrator may have born some resemblance to Hermann Karl von Keyserling, a Russian diplomat from Livonia who was accredited at the Royal Court in Warsaw (1733-44,1749-52, and 1762-64) and served as a teacher to the future king, Stanislaus II Augustus, or his son. Whereas the presentation of the fortress of Kamianets-Podilskyi, a Royal Army garrison, as the location where the confederate forces had gathered could have followed from an association with Adam Krasiński, the Bishop of Kamianets-Podilskyi and one of the leaders of the Bar movement. ${ }^{74}$

Speaking through the person of the major, the author appealed to the participants of the Bar movement to withdraw from the fight, striving to convince them that they were defending an unjust cause. 'Do not drown the environs of Warsaw in the blood of your fellow countrymen', pleaded Keyserling, and asked: 'do you want to become brutal murderers acting in

${ }^{74} \mathrm{Cf}$. Simon Davies, introduction to Discours aux confédérés catholiques de Kaminiek en Pologne. Par le major Kaiserling au service du roi de Prusse, in Les œuvres complètes de Voltaire, vol. 67: Writings of 1786, part 3, ed. Nicholas Cronk, Oxford, 2007, pp. 175-81. 
the guise of Catholics?'. ${ }^{75}$ He presented the events of Torun of 1724 as an example of Catholic cruelty. As previously in the Essai historique et critique sur les dissensions des Églises de Pologne, he stressed that the sole reason for the punishment which had befallen the Evangelicals of Torun was their profanation of the image of the Mother of God: 'the students grabbed the picture [...] and threw it into the mud. ${ }^{76}$ The narrator defended the participants of the riot who were sentenced to death, declaring that 'this was a terrible crime; however, the punishment was somewhat too severe. I would have preferred a measure of commensurateness to have been kept.' 77 According to the so-called 'Keyserling', the tragedy had occurred primarily because of the Jesuits. They, by readily fanning the flames of religious fanaticism, had stoked up a deep animosity towards dissenters. 'Hangings, beheadings, wheelings' were to bring comfort to the Catholics and lift their spirits. ${ }^{78}$ 'It was a beautiful sight, the Jesuit related, the public turned up in large numbers. We held a grand dinner for the judges, executioners, guards, delators and all those who had some share in our worthy work. ${ }^{79}$ The narrator observed that during the solemn meal, quotations were read from the Book of Psalms, among others 'The righteous Lord has cut asunder the necks of sinners' (Psalm 129.4) and 'Happy is the one who takes your babies and smashes them against the rocks' (Psalm 137.9).$^{80}$ The Jesuits, who were seeking severe punishment for the townspeople of Torun who had desecrated the image of the Mother of God, were themselves guilty of profaning the sacred book by perversely citing its fragments. It would appear that the members of the Society of Jesus were waiting solely for an opportunity for a fresh round of persecution. Keyserling's interlocutor speaks with gusto about the 'young people subjected to torture, mutilated, beheaded, burned, broken and dying on the wheel

75 'N'inondez pas les environs de Kaminieck du sang de vos compatriotes [...]. Voudriez-vous n'être que des homicides sanguinaires, sous prétexte que vous êtes catholiques?', [Voltaire], Discours aux confédérés catholiques de Kaminiek [sic!] en Pologne. Par le major Kaiserling au service du roi de Prusse, in idem, EFuvres complètes, vol. 27, 1879, pp. 76-77.

76 'Que de jeunes écoliers avaient pris chez eux une image de la Vierge, mère de Dieu, et qu'ils l'avaient laissée tomber dans la boue.' Ibid., p. 79.

77 'Je lui dis que ce crime était horrible; mais que le châtiment était un peu dur, et que j’y aurais désiré plus de proportion.' Ibid.

78 'Pendre, décapiter, rouer, brûler', ibid.

79 'Ce fut un spectacle admirable, tout était plein; nous donnâmes, au sortir du théâtre, un grand souper aux juges, aux bourreaux, aux geôliers, aux délateurs, et à tous ceux qui avaient coopéré à ce saint œuvre.' Ibid.

${ }^{80}$ Ibid. 
only because they had adored portraits resembling the Holy Virgin with insufficient eagerness, or because they had spoken of her without due reverence. ${ }^{81}$ The Jesuit added that a similar fate might soon befall the Polish king, the primate, and the Russian empress. It should be expected that, due to their infidelity, their blood will soon have to be spilled: "may he who does not listen to the assembly be treated as a pagan or a tax-collector. ${ }^{82}$ Keyserling turned to the confederates of Bar with the following question: 'do you not quiver with horror upon hearing such accounts? This then is the religion which you defend!' ${ }^{83}$

The recollection of the events of Torun presented in the Discours aux confédérés catholiques de Kaminiek en Pologne was not directly connected with the Russian offensive in Poland. It served neither to justify the military intervention of the court of Saint Petersburg nor to depict the Russian empress as an enlightened ruler. Instead, it formed part of Voltaire's long-standing campaign against the Catholic Church. Being a continuation of the threads that appeared in his earlier writings, it provided a pretext for accusing the Church - particularly the Jesuits, who constituted one of its foundations - of fanaticism, cruelty, and brutality towards Protestants.

Voltaire revisited the events of Torun in the first months of 1772 , having planned to write an introduction ridiculing superstitions, fanaticism, and intolerance to Antoine Le Blanc de Guillet's drama Les Druides. The play, which premièred on 7 March 1772, caused a sensation and a scandal and was taken off after only two performances. ${ }^{84}$ Although Voltaire ultimately abandoned the idea of penning the preface, he disclosed in a letter to the French diplomat Charles-Augustin de Ferriol d'Argental that he had intended to present therein the 'sufferings of the citizens who because of the efforts of the Jesuits had been sacrificed in Torun in 1724', the fate of Jean-François de la Barre, and those who had perished during the St Bartholomew's Day Massacre and through the actions of the Inquisition. All these instances were 'real sacrifices given in

81 'Il cita plusieurs exemples dans ce siècle même, dans ce siècle philosophique, de jeunes gens appliqués à la torture, mutilés, décollés, brûlés, rompus vifs, expirants sur la roue, pour n'avoir pas assez révéré les portraits parfaitement ressemblants de la sainte Vierge, ou pour avoir parlé d'elle avec inconsidération.' Ibid., p. 80.

82 'Qui n'écoute pas l'assemblée soit comme un païen ou un receveur des deniers publics.' Ibid., p. 79.

83 'Mes chers Polonais, ne frémissez-vous pas d'horreur à ce récit? Voilà donc la religion dont vous prenez la défense!', ibid., p. 80.

${ }^{84}$ Ronald S. Ridgway, La propagande philosophique dans les tragédies de Voltaire, Geneva, 1961, p. 196. 
the form of human blood'. ${ }^{85}$ Thus, the 'Bloodbath of Torun' would become part of the history of religious persecution as one of the most significant examples of the cruelty displayed by the Catholic Church. We cannot exclude that Voltaire was becoming strongly influenced by the events of 1724 . This supposition seems to be strengthened by the fact that the Torun issue appeared in the new edition of his Philosophical Dictionary. In the ninth section of Questions sur l'encyclopédie, which was also published in 1772, in the entry devoted to the prophet Hosea, Voltaire, citing a fragment from the Book of Hosea ('Let Samaria perish, because she hath stirred up her God to bitterness: let them perish by the sword, let their little ones be dashed, and let the women with child be ripped up', Hosea 14.1), explained the history of contemporary persecution against a confessional backdrop. Namely, in neither case - that of the Samaritans or of the denominations which did not recognize the primacy of the papacy - did the problem actually concern issues of religion. In the philosopher's opinion, the prophet Hosea condemned the Samaritans only because they made their sacrifices on Mount Gerizim, without using the agency of the Temple in Jerusalem. He wrote: 'they were schismatics who wanted to make their sacrifices in their homes, without having to send their monies to Jerusalem' ${ }^{86}$ The same fate befell the citizens of Torun, who had to give up their lives because they were not Catholics. Voltaire accentuated the drama of the events, pointing out that not the townspeople of Torun had been sentenced to death, but mere students ${ }^{87} \mathrm{He}$ argued that the members of the Catholic Church were obliged to persecute everyone who was not subordinate to the Pope: 'The Russians believe in the schismatic Greek religion, and, since they do not send their monies to Rome - as a professor supposedly told Voltaire at the University of Prague to whom he passed on the narration in the cited entry - we must exterminate them' ${ }^{88}$ Voltaire further con-

85 'Je regarde le supplice des citoyens qui furent immolés à Thorn en 1724 à la sollicitation des Jésuites, la mort affreuse du chevalier de la Barre, la st Barthelémi, et les arrêts de l'inquisition comme de véritables sacrifices de sang humain; et c'est ce que je me propose de faire entendre dans une préface et dans des notes d'une manière qui ne pourra choquer personne.' Voltaire to Charles Augustin Ferriol, Count d'Argental, 2 March 1772, D17619.

86 'Les Samaritains étaient des schismatiques qui voulaient sacrifier chez eux, et ne point envoyer leur argent à Jérusalem', Voltaire, Dictionnaire philosophique, vol. 4, in idem, Euvres complètes, vol. 20, 1879, p. 158.

87 'Quand les jésuites firent pendre dans Thorn, en 1724, de jeunes écoliers, c'est que ces pauvres enfants étaient schismatiques.' Ibid.

88 'Les Russes sont de la religion grecque schismatique; ils ne portent point leur argent à Rome: donc nous devons les exterminer', ibid. 
tended that the Church had been faithful to these principles for centuries, as the Hussites had met the same fate. He stressed emphatically throughout that the Catholic clergy was not interested in matters of dogma but in financial considerations alone. The residents of Torun had to perish, for 'they intended to retain their monies. ${ }^{\text {'8 }}$

I have not found anything in the philosopher's correspondence that would suggest that he was encouraged to utilize the 'Bloodbath of Torun' in his journalistic or literary writings by third persons. It would seem that Voltaire's interest in the riots was the result of his own inquisitiveness. His intention to cite the events of Torun in the introduction to Les Druides, the references made in Questions sur l'encyclopédie, and the fact that he juxtaposed them with the St Bartholomew's Day Massacre or the activities of the Inquisition permit us to put forward the supposition that Voltaire planned to turn the 'Bloody Court' of Torun into a canonical example of religious persecution, thereby making the year 1724 a landmark in the history of the European struggle for freedom of religion. Similarly, as with previous allusions to the events of Torun, the association with Polish affairs was only slight. Of greatest importance was a critique of the Church, accompanied by the implementation of the motto 'Écrasez l'infâme!'. If the philosopher had indeed made plans to use the issue of Torun', these were never put into effect.

In November 1772, when he was not yet aware of the exact scale of Prussian territorial acquisitions, Voltaire wrote thus to the Prussian king, Frederick II: 'It was in Torun that Copernicus discovered the true system of this world, while the astronomer Hevelius came from Gdańsk [Danzig]. Therefore both Torun and Gdańsk must belong to you'. Wrongly assuming that the treaty confirming the division of Poland had been signed in Potsdam, and not in Saint Petersburg, he spoke flatteringly of the political capabilities of the monarch whom he perceived as the originator of the concept of partition: 'It is said that it was planned by you, sir, and this I believe, for you are possessed of such genius. ${ }^{90}$ In his next letter to the Prussian monarch, which was sent in the first days of December 1772, Voltaire expressed his conviction that Frederick's reign in Royal Prussia would end the persecution of the territory's Protestants. Once again, the

89 'C'est ainsi que nous traitâmes les Hussites, qui voulaient aussi garder leur argent.' Ibid.

90 'J'ajouterai que c'est à Thorn que Copernic trouva la vrai système du monde, que l'astronome Hevelius était de Dantzik, et que par conséquent Thorn et Dantzik doivent vous apartenir. [...] On prétend que c'est vous, sire, qui avez imaginé le partage de la Pologne et je le crois parce qu'il y a là du génie et que le traitté s'est fait à Potsdam.' Voltaire to Frederick II, Ferney, 18 November 1772, D18019. 
philosopher juxtaposed the events of 1724 with the St Bartholomew's Day massacre and the case of Jean-François de la Barre. He wrote this type of cruelty, accompanied by stupidity, typical of a 'nation of monkeyish tigers', could not have occurred in the enlightened monarchy of the Hohenzollerns. ${ }^{91}$ When the Prussian king did not reference the issue of Torun in his correspondence, Voltaire took it up yet again in the spring of 1773. Still not knowing the course of the Polish-Prussian border, he made the following statement in a letter from the end of April: 'assuming that Torun will find itself in your monarchy, may I take the liberty of requesting that you ensure justice for the Holy Virgin Mary, to whom so many young students were sacrificed in 1724 . This respectable woman from Bethlehem did not expect that so much would be offered to her and her Son one day. Human blood has flowed for her a thousand times more often than for the pagan gods'. ${ }^{92}$ Voltaire thus anointed the Prussian king, making him the defender and at once avenger of mercy, justice and temperance. Frederick II touched upon the events of Torun only in mid-August 1773. Chastening the philosopher, he wrote: 'I see that the public likes to exaggerate certain happenings. ${ }^{93}$ He informed Voltaire that Torun had not been added to the Prussian monarchy. 'I cannot avenge the massacre of the innocent, of which the priests of the city must be ashamed'. He did, however, announce that he would erect a monument dedicated to Nicolaus Copernicus in Frombork (Frauenburg). 'Please, believe me, he wrote, whenever possible it is better to reward than to punish, to pay homage to a genius than to take revenge for cruelties committed many years ago. ${ }^{94}$ It is evident that the Prussian king was distancing himself from the 'Bloodbath of Torun'. Voltaire did not argue with the monarch's reservations. In a letter sent to Frederick II in the first days of September 1773, he ex-

91 'Cela est digne de la nation des tigres-singes qui a fait la Saint-Barthelemi; cela était digne de Thorn en 1724; et cela n'arrivera jamais dans vos états. Cela n'arrivera jamais dans vos États. [...] Pour moi je vous bénis, et je frémis tous les jours de l'exécrable aventure d'Abbeville [a reference to the case of François-Jean de la Barre J.K.].' The same to the same, Ferney, 8 December 1772, D18069.

92 'Supposé que Thorn soit en vôtre puissance, j'ose vous demander justice de la sainte vierge Marie, à laquelle on sacrifia tant de jeunes écoliers en l'année 1724. Cette bonne femme de Bethléem ne s'attendait pas qu'un jour on ferait tant de sacrifices à elle et à son fils. Le sang humain a coulé pour eux mille fois plus que pour les dieux païens', the same to the same, Ferney, 22 April 1773, D18331.

${ }_{93}$ 'Je vois que le public se complaît à exagérer les événements.' Frederick II to Voltaire, 12 August 1773, D18510.

94 'Croyez moi, il vaut mieux, quand on le peut, récompenser que punir, rendre des hommages au génie que venger des atrocités depuis longtemps commises.' Ibid. 
pressed pain and disbelief at the fact that Torun had remained within the Polish Commonwealth. 'I am sad to hear that Torun has not found itself under your rule; I am glad, however, that the tomb of Copernicus is now situated within the borders of your state. ${ }^{95}$ The philosopher portrayed the Prussian king as the founder of a new world, a man who had brought about an epochal breakthrough in Prussian and European politics. A juxtaposition of his achievements with Nicolaus Copernicus's discovery provides ample proof of this: 'I entreat you to erect a gnomon upon his ashes, so that each day at noon the sun may shine upon his remains, conjoining his concepts with yours. ${ }^{96}$

The possibility cannot be excluded that Voltaire removed the events of Torun from his agenda under the influence of Frederick II, who returned to them only with reluctance. Equally, however, we cannot rule out that Voltaire had understood that the memory of what had occurred in Torun in 1724 did not resonate with sufficient force. The enlightened public, just like Voltaire himself, associated Torun first and foremost with Nicolaus Copernicus.

By way of a summary, let us state that the court of Saint Petersburg, which shaped the diplomatic and military offensive against Poland and the concomitant propaganda activities, was not particularly concerned with reminding the world of the 'Bloodbath of Torun'. The collection of Voltairean correspondence published by Besterman does not provide any data that would allow us to conclude that the philosopher had been encouraged to take up the issue of the events of Torun by third persons. What is more, it does not contain even a hint suggesting that anyone was reminding the philosopher of the tumult. Obviously, we cannot reject the possibility that the matter had indeed been broached in a letter that is no longer extant. It is also worth noting that there are no propaganda materials concerning the 'bloodbath' in Voltaire's library. Perhaps Voltaire discussed the topic with one of the many guests who visited his residence near Geneva. The sources from which Voltaire obtained his information notwithstanding, we can put forward the supposition that he himself came upon the idea of presenting the events as a milestone in the development of confessional relations in Europe. His attempt, however, was a failure.

95 'Je suis fâché que Thorn n'apartienne point à Votre majesté; mais je suis bien aise que le tombeau de Copernic soit sous votre domination.' The same to the same, 4 September 1773, D18538.

96 'Elevez un gnomon sur sa cendre, et que le soleil remis par lui à sa place le salue tous les jours à midy de ses raions joints aux vôtres.' Ibid. 
Finally, we cannot agree with Larry Wolff, who, when referring to Voltaire's Essai historique et critique sur les dissensions des Églises de Pologne, stated that 'Such an essay against Catholicism in Poland followed naturally from the eighteenth-century press and pamphlet literature in Protestant England (and also in Prussia), which expressed outrage over Polish excesses, dating from the riots and executions at Thorn in $1724 .{ }^{97}$ The 'bloodbath' was already losing its topical appeal in the late 1720s, and in later decades of the Enlightenment ceased to be the subject of keen public interest. Although revisited in the nineteenth century, it was used as nothing more than a tool, 'regularly abused, both publicly and privately, in order to justify all the violations committed against Poland'. ${ }^{98}$

(Translated by Maciej Zakrzewski)

(Proofreading by Jan Czarniecki)

\section{Summary}

The following comments aim to present threads concerning the 'Tumult of Torun' in propaganda publications authored by Voltaire at the turn of the 1770s and in his correspondence. The author intended to provide an answer to the question as to how Voltaire used the motif of the 'Bloodbath of Torun' of 1724 in his works, why he recalled memories of the events, to what degree was he independent in this regard, and to what extent was he guided by instructions received from Saint Petersburg. I have not found anything in the philosopher's correspondence that would suggest that he was encouraged to utilize the 'Tumult of Torun' in his journalistic or literary writings by third persons. It would seem that Voltaire's interest in the happenings of 1724 was the result of his own inquisitiveness.

(Translated by Maciej Zakrzewski)

(Proofreading by Jan Czarniecki)

${ }^{97}$ Larry Wolff, Inventing Eastern Europe: The Map of Civilization on the Mind of the Enlightenment, Stanford, CA, 1996, p. 263.

${ }_{98}$ [Kazimierz Jarochowski], 'Sprawa toruńska z roku 1724', in idem, Opowiadania i studia historyczne, 2 vols, Poznań, 1860-63, vol. 2, pp. 137-94 (p.141). 


\section{Bibliography}

Arkhiv vneshnei politiki Rossiiskoi imperii, Moscow fonds 80, series 1, no. 1095.

Rossiiskaia natsional'naia biblioteka, Saint Petersburg Biblioteka Vol'tera, 9-335, no. 7828.

Acte de la confédération des nobles et citoyens du Grand Duché de Lituanie du rit grec et de deux confessions évangéliques, fait à Sluck l'an 1766 le 20 de mars, [n.p.]: [n. pub.], [1767].

Baranowski, Henryk, Bibliografia miasta Torunia, 2 vols, Toruń: TNT, 1996-99, vol. 1: Do roku 1971, 1999.

Beauvois, Daniel, and Emanuel Rostworowski, introduction to Essai historique et critique sur les dissensions des Églises de Pologne, in Les œuvres complètes de Voltaire, vol. 63A: Euvres de 1767, ed. William H. Barber, Ulla Kölving, Oxford: Voltaire Foundation, 1990, pp. 241-60.

Bellingradt, Daniel, Flugpublizistik und Öffentlichkeit um 1700: Dynamiken, Akteure und Strukturen im urbanen Raum des Alten Reiches, Stuttgart: Steiner, 2011.

Burdowicz-Nowicki, Jacek, 'Polityka Piotra I w związku ze sprawą toruńską 1724 r.', in W cieniu wojen i rozbiorów: Studia z dziejów Rzeczypospolitej XVIII i początków XIX wieku, ed. Urszula Kosińska, Dorota Dukwicz and Adam Danilczyk, Warsaw: Neriton, 2014.

Büsching, Anton Friderich, Neue Erdbeschreibung. Erster Theil, welcher Dänemark, Norwegen, Schweden, das ganze rußische Kaisertum, Preussen, Polen, Hungarn und die europäische Türkey, mit denen dazu gehörigen und einverleibten Ländern, enthält, Hamburg: Bohn, 1754.

Chassaigne, Marc, Le procès du chevalier de La Barre, Paris: Gabalda, 1920.

Confédération faite par les dissidents du royaume de Pologne à Thorn le 20 mars l'année 1767, [n.p.]: [n. pub.], [1767].

Davies, Simon, introduction to Discours aux confédérés catholiques de Kaminiek en Pologne. Par le major Kaiserling au service du roi de Prusse, in Les œuvres complètes de Voltaire, vol. 67: Writings of 1786, part 3, ed. Nicholas Cronk, Oxford: Voltaire Foundation, 2007, pp. 175-81.

Déclaration de la part de Sa Majesté, l'impératrice de toutes les Russies à Sa Majestéle roi et à la République de Pologne, [Saint Petersburg]: [n. pub.], [1767].

Diplomaticheskaia perepiska Imperatritsy Ekateriny II, part 4: 1766-1767, published by Fiodor A. Biuler, Saint Petersburg: Universitetskaia tipografiia, 1889, SIRIO, vol. 67.

Dygdała, Jerzy, 'W cieniu głębokich konfliktów wyznaniowych (1719-1732)', in Historia Torunia, ed. Marian Biskup, 3 vols, Toruń: Wydawnictwo TNT, 19922006, vol. 2, part 3: Między barokiem i oświeceniem 1660-1793, ed. Jerzy Dygdała, Stanisław Salmonowicz and Jerzy Wojtowicz, 1996, pp. 175-205. 
Dźwigała, Wanda, 'Voltaire and Poland: the Historical Works', Studies on Voltaire and the Eighteenth Century, 267, 1989, pp.103-18.

Dźwigała, Wanda, 'Voltaire's Sources on the Polish Dissident Question', Studies on Voltaire and the Eighteenth Century, 241, 1986, pp. 187-202.

Encyclopédie ou dictionnaire raisonné des sciences, des arts et des métiers, 35 vols, Paris: Briasson, David, Le Breton, Durand, 1751-72, vol. 4, 1754, vol. 6, 1756, vols $12,13,16,1765$.

Exposition des droits des dissidents, joints à ceux des puissances intéressées a les maintenir, Saint Petersburg: [n. pub.], 1766.

Feinauer, Samuel, '«Tragoedia Thoruniensis»: Ein europäisches Medienereignis des frühen 18. Jahrhunderts und sein Widerhall in Diplomatie und Publizistik', unpublished doctoral dissertation, Universität Stuttgart, 2017.

Feldman, Józef, Sprawa dysydencka za Augusta II, Cracow: Krakowska Spółka Wydawnicza, 1924.

Felice, Fortunato Bartolomeo de, Encyclopédie ou dictionnaire universel raisonné des connaissances humaines, 58 vols, Yverdon: [n. pub.], 1770-80, vol. 14, 1772.

Fiszer, Stanisław, L'image de la Pologne dans l'œuvre de Voltaire, Oxford: Voltaire Foundation, 2001.

Forycki, Maciej, Anarchia polska w myśli oświecenia: Francuski obraz Rzeczypospolitej szlacheckiej u progu czasów stanisławowskich, Poznań: Wydawnictwo Poznańskie, 2004.

Fundamenta liberae religionis evangelicorum, reformatorum et graecorum in Regno Poloniae et Magno Ducatu Lithvaniae... / Deduction fondamentale des libertés de religion dont les lutheriens, les reformes et les grecs doivent jouir dans Le Royaume de Pologne et Le Royaume de Lithuanie..., [n.p.: n. pub.], 1764.

Garrisson, Janine, L'Affaire Calas, miroir des passions françaises, Paris: Fayard, 2004.

Gay, Peter, Voltaire's Politics: The Poet as Realist, New Haven, CT: Yale University Press, 1988.

Gooch, George Peabody, 'Catherine the Great and Voltaire', The Contemporary Review, 182, 1952, pp. 214-20, 288-93.

Gooch, George Peabody, 'Voltaire as Historian', in George Peabody Booch, Catherine the Great and Other Studies, London: Longmans, Green \& Co, 1954, pp.199-274.

Gorbatov, Inna, Catherine the Great and the French Philosophers of the Enlightenment: Montesquieu, Voltaire, Rousseau, Diderot and Grimm, Bethesda, MD: Academica Press, 2006.

Gottsched, Johann Christoph, Briefwechsel: Unter Einschluß des Briefwechsels von Luise Adelgunde Victorie Gottsched: Historisch-kritische Ausgabe, Berlin and New York: Gruyter, 2007-, vol. 2: 1731-1733, published by Detlef Döring, Rüdiger Otto, Michael Schlott, 2008.

Grosses vollständiges Universal-Lexicon aller Wissenschaften und Künste, 68 vols, Leipzig and Halle: Zedler, 1732-54, vol. 43, 1745.

Inchauspé, Dominique, L'intellectuel fourvoyé: Voltaire et l'affaire Sirven, 1762-1778, Paris: Michel, 2004. 
[Jabłoński, Daniel Ernest], Jura et libertates dissidentium in religione christiana, in Regno Poloniae, et M.D. Lithuaniae..., Stargard: Joh. Nicol. Ernestus, 1715.

[Jarochowski, Kazimierz], 'Sprawa toruńska z roku 1724', in idem, Opowiadania i studia historyczne, 2 vols, Poznań: J.K. Żupański, 1860-63, vol. 2, pp. 137-94.

Konfederacya jchmciow panow dissydentow $z$ Wielkiey y Małey Polski y z Pruss $w$ Toruniu uchwalona dnia 20 marca Roku Panskiego 1767, [n.p.]: [n. pub.], [1767].

Konfederacya rycerstwa y obywatelow W. X. Litt. tak religii staroruskiey jako tez oboyga wyznania ewangelickiego, zaczęta w Słucku, roku 1767 dnia 20 miesiaca..., [n.p.]: [n. pub.], [1767].

Kordel, Jacek, 'Catherine the Great, Voltaire, and the Russian Intervention in Poland, 1767-1771', in Recht zur Intervention - Pflicht zur Intervention?: Zum Verhältnis von Schutzverantwortung, Reputation und Sicherheit in der Frühen Neuzeit, ed. Christoph Kampmann, Julian Katz and Christian Wenzel, Baden-Baden: Nomos, 2021, pp. 499-543.

Kordel, Jacek, 'Królestwo anarchii’: W poszukiwaniu nowożytnych wyobrażeń o Rzeczypospolitej i jej mieszkańcach, Warsaw: Narodowe Centrum Kultury, 2020.

Kraushar, Aleksander, Sprawa Zygmunta Unruga: Epizod historyczny z czasów saskich 1715-1740, 2 vols, Cracow: Gebethner i Spółka, 1890.

Le Clerc, Jean, Epistolario, published by Maria Grazia Zaccone-Sina and Mario Sina, 4 vols, Firenze: Olschki, 1987-97, vol. 4: 1719-1732 e indici generali, 1997.

Lettre de monsieur Panin au prince Repnin, [n.p.], [1767].

Lukowski, Jerzy T., The 'Szlachta' and the Confederacy of Radom, 1764-1767/68: A Study of the Polish Nobility, Rome: Institutum Historicum Polonicum Romae, 1977, Antemurale, 21.

Lukowski, Jerzy T., ‘Unhelpful and unnecessary: Voltaire’s Essai historique et critique sur les dissensions des Églises de Pologne (1767)', in Voltaire et ses combats: Actes du Congres International 'Voltaire et ses combats...' tenu du 29 septembre au 5 octobre 1994 a Oxford et a Paris, ed. Ulla Kölving and Christiane Mervaud, Oxford: Voltaire Foundation, 1997, pp. 645-54.

Łubieńska, Maria Cecylia, Sprawa dysydencka 1764-1766, Warsaw: Gebethner i Wolff, 1911.

Milewska-Kozłowska, Joanna, ‘Druki dotyczące Tumultu Toruńskiego w zbiorach starych druków Biblioteki Uniwersytetu Mikołaja Kopernika w Toruniu', Rocznik Toruński, 34, 2007, pp. 207-46.

Mittag, Johann Gottfried, Leben und Thaten Friedrich Augusti II. des Großen, Königs der Pohlen, und Churfürstens zu Sachsen, Leipzig: Martini, 1733.

Mühling, Christian, Die europäische Debatte über den Religionskrieg (1679-1714): Konfessionelle Memoria und internationale Politik im Zeitalter Ludwigs XIV., Göttingen: Vandenhoeck \& Ruprecht, 2018.

Müller, Michael G., 'Anmerkungen zur Diskussion über religiöse Toleranz und Dissidentenfrage in Polen in der zweiten Hälfte des 18. Jahrhunderts', Kwartalnik Neofilologiczny, 55, 1998, pp. 417-26.

Müller, Michael G., 'Toleration in Eastern Europe: The Dissident Question in Eighteenth-Century Poland-Lithuania', in Toleration in Enlightenment Europe, 
ed. Ole P. Grell and Roy Porter, Cambridge: Cambridge University Press, 1999, pp. 212-29.

Nosov, Boris V., Ustanovlenie rossiiskogo gospodstva $v$ Rechi Pospolitoi, 1756-1768 gg., Moscow: Indrik, 2004.

Preussens Staatsverträge aus der Regierungszeit König Friedrichs I., published by Victor Loewe, Leipzig: Hirzel, 1923.

Rhode, Gotthold, Brandenburg-Preußen und die Protestanten in Polen 1640-1740, Leipzig: Hirzel, 1941.

Ridgway, Ronald S., La propagande philosophique dans les tragédies de Voltaire, Geneva: Institut et Musée Voltaire, 1961.

Rostworowski, Emanuel, 'Wolter a Polska', KH, 75, 1968, 4, pp. 849-64.

Salmonowicz, Stanisław, 'O toruńskim tumulcie z roku 1724', OiRP, 28, 1983, pp. 161-84.

Schulze Wessel, Martin, 'Religiöse Intoleranz, grenzüberschreitende Kommunikation und die politische Geographie Ostmitteleuropas im 18. Jahrhundert', in Europäische Öffentlichkeit: Transnationale Kommunikation seit dem 18. Jahrhundert, ed. Jörg Requate and Martin Schulze Wessel, Frankfurt: Campus, 2002, pp. 63-78.

Thompson, Andrew C., Britain, Hanover and the Protestant Interest 1688-1756, Woodbridge: Boydell Press, 2006.

Wilberger, Carolyn, Voltaire's Russia: Window on the East, Oxford: Voltaire Foundation, 1976.

Wolff, Larry, Inventing Eastern Europe: The Map of Civilization on the Mind of the Enlightenment, Stanford, CA: Stanford University Press, 1996.

Voltaire, Correspondence and Related Documents, ed. Theodore Besterman, 51 vols, Oxford: Voltaire Foundation, 1968-77, vols 5 (letters D1439-1729), 31 (D1359614077), 32 (14078-14634), 36 (16127-16678), 38 (17279-17842), 39 (17843-18406), 40 (D18407-18967), Les œuvres complètes de Voltaire, vols 85-135, vols 89, 115, $116,120,122,123,124$.

Voltaire, Euvres complètes, 52 vols, ed. Louis Moland, Paris: Garnier, 1877-85, vols $12,13,16,1878$, vols 20, 25-27, 1879.

Voltaire [= Mittag Johann Gottfried], Leben und Thaten Friedrich Augusti II. des Großen, Königs der Pohlen, und Churfürstens zu Sachsen, Frankfurt and Leipzig: [n. pub.], 1733.

Wołoszyński, Ryszard, Polska w opiniach Francuzów XVIII wieku, Warsaw: PWN, 1964.

Zielińska, Zofia, 'Głos rosyjskiego arystokraty o Polsce z 1766 r.', Miscellanea Historico-Archivistica, 11, 2000, pp. 335-44.

Zielińska, Zofia, Polska w okowach 'systemu pótnocnego' 1763-1766, Cracow: Arcana, 2010.

Bi og r a phy: Jacek Kordel - born in 1988, is an assistant professor at the Faculty of History, University of Warsaw. He studied history in Warsaw and Berlin (2007-2012). His doctoral thesis concerned the foreign policy of Saxony in the 
second half of the eighteenth century (2017, Faculty of History, University of Warsaw; it received prizes from the Prime Minister of the Republic of Poland and the Polish Society for Eighteenth-Century Studies). Jacek Kordel's research interests focus on the history of modern diplomacy, the history of the Holy Roman Empire in the eighteenth century, and opinions about Poland in the period of the Enlightenment. His most important publications include: $Z$ Austria czy z Prusami?: Polityka zagraniczna Saksonii 1774-1778, Cracow: Arcana, 2018; 'Królestwo anarchii': W poszukiwaniu nowoży tnych wyobrażeń o Rzeczypospolitej i jej mieszkańcach, Warsaw: Narodowe Centrum Kultury, 2020, and Sachsen, Preußen und der Kaiserhof im Streit um die Schönburgischen Herrschaften, 1774-1779, Leipzig: Leipziger Universitätsverlag, 2021. 